\title{
UNIVERSALISM OF HUMAN RIGHTS: NOTION OF GLOBAL CONSENSUS OR REGIONAL IDEA
}

\author{
Krzysztof Orzeszyna*
}

\begin{abstract}
This article deals with the universal nature of human rights recognised by all civilisations and legal systems. The important thing is that the actions of the state are consistent with the content of these rights is justified by the fact that they protect the dignity of every human being and enable cooperation between people. Universal treaties impose the same international legal obligations in the field of human rights on as many states as possible. Regional treaties perform this function in relation to a group of states. It seems, however, that for the full protection of an individual's rights, the ideas of universalism and regionalism of human rights need to complement each other. No regional system can exist if it is inconsistent with the norms and principles of the Universal Declaration of Human Rights.
\end{abstract}

Keywords: universalism, regionalism, human rights, human dignity

\section{INTRODUCTION}

The universal nature of human rights has been recognised by all civilisations and legal systems, as evidenced by the universal acceptance of the Universal Declaration of Human Rights ${ }^{1}$. The authors often focus on

Dr. habil. Krzysztof Orzeszyna, Associate Professor, Department of Human Rights and Humanitarian Law, Faculty of Law, Canon Law and Administration, The John Paul II Catholic University of Lublin; correspondence address: Al. Racławickie 14, 20-950 Lublin, Poland; e-mail: krzysztof.orzeszyna@kul.pl; https://orcid.org/0000-0003-0733-6028. 
presenting the universality of geography, history, culture and political diversity. It is also possible to study universalism in three aspects: territorial, subjective and functional. Territorial approach means that human rights apply globally, both inside and outside planet earth. Subjective approach means that human rights apply to all people equally, without any subjective exclusions. The functional approach requires the creation of universal means of protection that can be used by all people. Universalism does not mean, however, that there cannot be certain differences in local and regional approaches to human rights ${ }^{2}$.

However, universalism raises questions about the definition of the concept of universality. When answering this question, particular attention should be paid to whether the content of provisions contained in treaties and its acceptance is universal. The function of universal treaties is to impose the same international legal obligations in the field of human rights on the largest possible number of countries in the world. Regional treaties fulfil a similar function in relation to a given group of states. This gives rise to the question of the possibility of implementing the ideas of universalism and regionalism of human rights and their mutual complementation. It is emphasised that no regional system can exist if it is inconsistent with the norms and principles of the Universal Declaration of Human Rights ${ }^{3}$. The universality of these rights is justified by the fact that they protect the dignity of every human being and enable cooperation between people.

\section{UNIVERSALISM IN THE PROTECTION OF HUMAN RIGHTS}

The principle of the universalism of human rights presupposes that everyone is entitled to these rights because of their humanity and so they apply wherever there is a human being. The universality of human rights is justified by reference to the dignity of the human person. It is the value

1 Anna Michalska, Prawa cztowieka w systemie norm międzynarodowych (Warszawa \& Poznań: Państwowe Wydawnictwo Naukowe, 1982), 292.

2 Arnold Rainer, "Reflections on the Universality of Human Rights," Ius Gentium: Comparative Perspectives on Law and Justice, no. 1 (2013): 1-12.

3 Arthur Henry Robertson, Human Rights in the World (Manchester: Manchester University Press, 1972), 158-160. 
of dignity that underlies the concept of human rights ${ }^{4}$. Universalism in the protection of human rights means basing this protection on international legal instruments of universal application. In practice, these are international instruments that have been developed within the framework of the United Nations $(\mathrm{UN})^{5}$. In fact, the universalism of human rights implies the assumption of their universality and applicability as a concept everywhere in the world and for everyone. Universalism is not an attempt to impose a description of a reality in which human rights are universally respected ${ }^{6}$.

Human rights treaties have been adopted under the auspices of the UN, which is the most universal international organisation. It has even been joined by entities such as the Holy See, which has ratified the Convention on the Rights of the Child ${ }^{7}$, and some territories such as Hong Kong, now a special administrative region of the People's Republic of China, which has recognised the rights contained in the International Covenant on Civil and Political Rights ${ }^{8}$. Moreover, although China is not bound by this treaty, it has accepted its obligations. Hence, it is assumed that even if no agreement has been reached on the axiological justification of individual provisions, there is agreement as to the practical goals to be achieved. From a purely legal perspective, it is assumed that the consolidation of the universal nature of human rights in international documents, such as the Universal Declaration of Human Rights ${ }^{9}$, the Charter

4 Krzysztof Orzeszyna, Michał Skwarzyński, and Robert Tabaszewski, Prawo międzynarodowe praw cztowieka (Warszawa: C.H. Beck, 2020), 20.

5 Maciej Lubiszewski, "Kodyfikacja ochrony praw człowieka w systemach regionalnych," in Prawa cztowieka i ich ochrona, ed. Bożena Gronowska et al. (Toruń: Wydawnictwo Dom Organizatora, 2010), 78-79.

6 Michał Balcerzak, Podstawy międzynarodowej ochrony praw cztowieka (Toruń: Towarzystwo Naukowe Organizacji i Kierownictwa „Dom Organizatora”, 2017), 42.

7 UN, Convention on the Rights of the Child adopted and opened for signature, ratification and accession by General Assembly resolution 44/25 of 20, UN Doc. No. 27531 November 1989.

8 UN, International Covenant on Civil and Political Rights (ICCPR) (adopted on 16 December 1966; entered into force on 23 March 1976), UNTS 999:171.

9 UN, Universal Declaration of Human Rights adopted 10 December 1948, G.A. Res. 217A(III), U.N.Doc. A/810 at 71 (1948). 
of the United Nations ${ }^{10}$ and international treaties, is sufficient to state that human rights are universal in a normative or juridical sense ${ }^{11}$. It is recognised that the catalogue of human rights contained in the documents of international law includes certain material and spiritual needs that are universal and permanent, which implies the universal nature of human rights ${ }^{12}$. Each individual has equal and inalienable rights resulting from their inherent dignity ${ }^{13}$.

The universalist tendency is reinforced by the jurisprudence and interpretation adopted by the Human Rights Committee in Geneva, which has recognised that in the case of state succession, a new state resulting from the division of a former state is bound by the human rights treaties adopted by the former state and succession is automatic ${ }^{14}$. Moreover, the committee has found that a human rights treaty cannot be terminated as no termination clause has been foreseen. This interpretation is based on a common principle: human rights treaties are not made for states, but for people. Since a state has committed itself to protecting them, no other action must lead to questioning it. This is a correct but quite progressive thesis which, in borderline situations, may actually even lead to a derogation of the general public international law ${ }^{15}$.

If we consider international documents in the field of human rights and the number of their ratifications, we will notice that the International Convention on the Rights of the Child is the most frequently ratified document. Namely, it has been ratified by 196 countries (except the United States and Somalia). It is followed by the Convention on the Elimination

10 UN, Charter and Statute of the International Court of Justice, signed on 26 June 1945 at the San Francisco Conference.

11 Balcerzak, Podstawy, 42.

12 Michalska, Prawa cztowieka, 294.

13 Orzeszyna, Skwarzyński, and Tabaszewski, Prawo międzynarodowe, 22.

14 HRC General Comment No. 6, Compilation of General Comments and General Recommendations Adopted by Human Rights Treaty Bodies, U.N. Doc. HRI/GEN/1/ Rev.1of 1997.

15 Jean Dhommeaux, "Universalisme et régionalisme(s)," in Dictionnaire des Droits de l'Homme, dir. Joël Andriantsimbazovina, Hélène Gaudin, Jean-Pierre Marguénaud, Stéphane Rials, and Frédéric Sudre (Paris: Quadrige/PUF, 2008), 959. Maciej Lubiszewski, "Kodyfikacja ochrony praw człowieka w systemach regionalnych," in Prawa cztowieka i ich ochrona, ed. Bożena Gronowska et al. (Toruń: Wydawnictwo Dom Organizatora, 2010), 78-79. 
of All Forms of Discrimination against Women, ratified by 180 states (except the United States and Iran, among others). Next are the International Covenant on Civil and Political Rights and the Covenant on Economic, Social and Cultural Rights that have been ratified by 174 and 170 states, respectively. However, it should be emphasised that China has not ratified the former and the United States has not ratified the latter ${ }^{16}$. However, the numbers indicated should be approached with some caution. Some countries are more important in the international arena, while China's failure to ratify the International Covenant on Civil and Political Rights is solely due to the country's special interest.

It is also known that the ratifications of individual international instruments do not have the same weight and importance. Moreover, it is also assumed that in addition to the visible element of non-universality, elements of universality are also formed ${ }^{17}$. For example, a country that does not practice torture may not be willing to ratify the 1984 Convention against Torture. It may assume that since there is no torture or inhuman or degrading treatment or punishment on the territory of his country, such a situation is universal, and torture is not a problem for other countries, especially for the same system ${ }^{18}$. The important thing is that the actions of the state are consistent with the content of this instrument. Moreover, it seems unnecessary to multiply the ratifications of documents with similar content as this may ultimately harm one of these instruments. It is more important for the state to respect human rights than to ratify further conventions with similar content. It seems that the purpose of subsequent conventions - especially those ensuring effective means of controlling their observance - is to strengthen the protection of an individual as compared to that resulting from the existing provisions ${ }^{19}$.

Paying attention to the apparent universalism of conventional law, one cannot ignore the issue of reservations to treaties. Two attitudes to this

16 UN, International Covenant on Economic, Social and Cultural Rights (ICESCR) (adopted on 16 December 1966; entered into force 3 January 1976), UNTS 993:3.

17 Dhommeaux, "Universalisme," 959.

18 In practice, this concerned Sweden, whose representatives visited nursing homes in Bulgaria under the CAT mechanism.

19 It is clearly visible in the example of the EU and the relationship of the EU system to the system of the Council of Europe and the constitution of the its Member States. 
problem can be adopted: prohibiting the raising of objections and privileging the content and normativity of an instrument by limiting its universality, or accepting the objections raised and privileging universality by limiting normativity. Is it more important that fewer countries commit more or that more countries commit less? It is impossible to have the attributes of universality and normativity at the same time. International human rights law is also in favour of universality. The reservations are numerous and limit the involvement of states when implemented, in some cases because of their general nature ${ }^{20}$. This is the case for some Islamic countries when it comes to the Convention on the Rights of the Child. The solution to this problem is not facilitated by the Vienna Convention on the Law of Treaties ${ }^{21}$, the provisions of which provide for a solution in the form of an objection leading to the actual failure to respond to the reaction of states due to their lack of interest, interest or insufficient resources ${ }^{22}$.

The protection of universalism is based on arguments related to the dignity of the human person, as well as cultural values such as justice, mutual respect, fraternity and social cooperation ${ }^{23}$. The argument for the principle of universalism is the reference to human needs - identical regardless of cultural or political differences ${ }^{24}$. An essential aspect in justifying the principle of universalism may be recognition of human rights as a supra-cultural civilisation achievement resulting from efforts taken to tame barbarism, oppression, brutality and disrespect for human life and so $\mathrm{on}^{25}$. The universalism of human rights facilitates the introduction and implementation of the principle of sustainable development ${ }^{26}$.

20 Robert Tabaszewski, "The Permissibility Of Limiting Rights And Freedoms In The Europe-an And National Legal System Due To Health Protection," Review of European and Comparative Law 3 (2020): 53-89, https://doi.org/10.31743/recl.6100.

21 UN, Vienna Convention on the Law of Treaties, May 23, 1969, Vienna, 1155 U.N.T.S.331, 8I.L.M. 679.

22 Dhommeaux, "Universalisme," 960.

23 Wiktor Osiatyński, Prawa cztowieka i ich granice (Kraków: Znak, 2011), 252.

24 Walter Kälin and Jörg Künzli, The Law of International Human Rights Protection (Oxford: Oxford University Press, 2010), 28.

25 Osiatyński, Prawa cztowieka, 253.

26 See: Krzysztof Orzeszyna and Robert Tabaszewski, "The legal activities taken by local authorities to promote sustainable development goals: Do the Polish local authorities need to adopt new local strategies?," Lex Localis - Journal of Local Self-Government 4 (2021); 
However, it should be noted that despite civilised nations having recognised universality, the universal system is still largely imperfect at this stage. This is confirmed by the statistics of submitted declarations. Currently, 116 states have accepted the jurisdiction of the Human Rights Committee, and an increasing number of states have also accepted the jurisdiction of the Committee against Torture and the Committee on the Elimination of Racial Discrimination. Moreover, the use of comments leaves much to be desired as they are not always considered obligatory due to the nature of the committees themselves ${ }^{27}$.

\section{PLURALISM OF THE REGIONAL SYSTEMS OF HUMAN RIGHTS PROTECTION AS A PRACTICAL EXPRESSION OF PARTICIPATION IN UNIVERSALITY}

Among the main arguments for creating regional systems of human rights protection is the diversity of the modern world. Therefore, it is emphasised that it is currently impossible to guarantee equal rights and freedoms by all states to the extent and at the level set out by the Covenants. Article 52 of the Charter of the United Nations is interpreted in the considerations on human rights as the recognition and acceptance of regional treaties subject to their compliance with universal treaties ${ }^{28}$. Therefore, it is believed that regional treaties may be a stage in reaching full agreement on a universal scale, not only as to the catalogue of rights, but also on the methods of their implementation. When work began on the development of the Convention for the Protection of Human Rights and Fundamental Freedoms in 194929, the bodies of the Council of Europe decided

Robert Tabaszewski, "Achieving the Sustainable Development Goals in Europe and East Asia: role of region-al organizations in monitoring right to good health and well-being," Ius Novum 2 (2019): 250-269, https://doi.org/10.26399/iusnovum.v13.2.2019.25/r.k.tabaszewski.

27 Dhommeaux, "Universalisme," 962.

28 Thomas Buergenthal, "International and Regional Human Rights Institutions: Some Exemples of their Interaction," Texas International Law Journal 12 (1977): 323.

29 Council of Europe, European Convention of Human Rights and Fundamental Freedoms, Rome, 4 November 1950 as amended by Protocols Nos. 11 and 14 supplement- 
that it should take into account the existing UN acquis in the field of international protection of human rights ${ }^{30}$. Hence, it is noted that most regional instruments refer to universal instruments such as the Universal Declaration of Human Rights. This is the case with the Preamble to the Convention for the Protection of Human Rights and Fundamental Freedoms, which states that:

"Considering that this Declaration [the Universal Declaration of $\mathrm{Hu}$ man Rights - K.O.] aims at securing the universal and effective recognition and observance of the Rights therein declared... as the governments of European countries... Have agreed... to take the first steps for the collective enforcement of certain of the rights stated in the Universal Declaration(...)".

The American Convention on Human Rights emphasises the Universal Declaration of Human Rights, as does the Protocol of San Salvador of 17 November 1988. Considering the possibility of conflicts between the proposed American Convention and the Covenants, in 1967, the Council of the Organization of American States turned to its member states, which expressed an almost universal intention to ratify the Covenants. However, these states postulated that the former regional convention should be compatible with them in its basic assumptions ${ }^{31}$. The African Charter on Human and Peoples' Rights refers to the Charter of the United Nations and to the Universal Declaration of Human Rights. The African Charter on the Rights and Welfare of the Child refers in a synthetic manner to the instruments of the Organisation of African Unity, the UN, in particular to the International Convention on the Rights of the Child ${ }^{32}$.

In its advisory opinion of 24 September 1982, the Inter-American Court of Human Rights affirmed that: 'A certain tendency to integrate the regional and universal systems for the protection of human rights can be perceived.' The preamble recognises that the principles underlying the American Convention on Human Rights are also those promulgated

ed by Protocols Nos. 1, 4, 6, 7, 12, 13 and 16, ETS No. 5: ETS No. 009, 4: ETS No. 046, 6: ETS No. 114, 7: ETS No. 117, 12: ETS No. 177.

30 Arthur Henry Robertson, Human Rights in Europe (Manchester: Manchester University Press, 1963), 6-16.

31 OEA/ser. G/IV C 2/787, Rev. 3.

32 Dhommeaux, "Universalisme," 961. 
in the Universal Declaration of Human Rights ${ }^{33}$. On numerous occasions, the court invokes general observations of the Human Rights Committee ${ }^{34}$, decisions of the Human Rights Committee, rulings of the European Court of Human Rights, and even decisions of the African Commission on Human and Peoples' Rights ${ }^{35}$.

This jurisprudence is complementary to reinforcing, for example, a universal tendency towards the abolition of the death penalty ${ }^{36}$. Similarly, there is a regional tendency to universalise one or the other norm. This is the case of the Inter-American Court of Human Rights, among others, which has recognised that 'in the present state of evolution of international law, the fundamental principle of equality and non-discrimination has entered into the domain of ius cogens ${ }^{37}$.

The relations between these systems show the pluralism of the forms expressed, inter alia, in autonomy with regard to the interpretation of rules, by each instrument and also a firm will not to confuse controls. Thus, the Human Rights Committee did not approve the interpretation of the International Covenant on Civil and Political Rights in the light of the provisions of the European Convention on Human Rights on freedom of expression, as was requested by many states which raised objections or made interpretative declarations in this regard. Therefore, the covenant has its own interpretation of the law. The autonomous concepts of 'civic' rights and 'similar matters' are the evidence of this autonomy ${ }^{38}$.

There are many similarities between the covenants and regional conventions, so emphasising the differences is unjustified. The criterion for creating regional systems should be identical or similar political, social,

33 Opinion, Par. 41, see: Robert Tabaszewski, "Międzyamerykański Trybunał Praw Człowieka jako panamerykański organ sądowniczy," in Katarzyna Krzywicka and Joanna Kaczyńska, Oblicza Ameryki Eacińskiej (Lublin: Wydawnictwo UMCS, 2010), 89-90.

34 Opinion of 1 October 1999, Par. 113-115.

35 Inter-American Court of Human Rights, Opinion of 17 September 2003, \$90-95, Par. 90-95.

36 ECtHR Judgement of 12 May 2005, Case Öcalan v. Turkey, application no. 46221/99, hu-doc.int; Human Rights Committee, the judge's comment against Canada of 5 August 2003; Inter-American Court of Human Rights, Opinion of September 1983.

37 Inter-American Court of Human Rights, Opinion of 17 September 2003, \$90-95.

38 Dhommeaux, "Universalisme," 960. 
economic and cultural elements. It would therefore be unjustified to give different meanings to identical or similar phrases only because they appear in different international instruments, the more so as the covenants and regional conventions were not inspired by different concepts of human rights ${ }^{39}$.

General instruments and some special instruments sometimes exist in the form of two documents. In addition to the two covenants of 1966, in Europe, there are the Convention for the Protection of Human Rights and Fundamental Freedoms and the European Social Charter. In America, on the other hand, there are the Pact of San Jose, Costa Rica and the Protocol of San Salvador. The abolition of the death penalty is provided for in the Protocol of the International Covenant on Civil and Political Rights, two protocols (6 and 13) to the Convention for the Protection of $\mathrm{Hu}-$ man Rights and Fundamental Freedoms and the Protocol to the American Convention. Despite the fact that there is the International Convention on the Rights of the Child, a different convention has been developed in the African system. This competitiveness is only important for those states which wish to ratify both of these documents. This situation leads either to a refusal to ratify or to duplication of ratified documents ${ }^{40}$. However, it should be emphasised that it seems pointless to sign regional treaties, the content of which will be a faithful repetition of universal treaties, unless it is done in order to activate a control mechanism ${ }^{41}$. Both universal and regional treaties should be applied complementarily. The principle of complementary application of universal and regional treaties means that an individual may rely on this international instrument which gives them fuller and more effective protection of their rights. Only by adopting such an interpretation is it possible to apply the regional covenants and treaties simultaneously in a way that will guarantee the fullest protection of human rights.

39 Michalska, Prawa cztowieka, 297.

40 Dhommeaux, "Universalisme," 961.

41 Michalska, Prawa cztowieka, 306. 


\section{CONCLUSIONS}

The universal nature of human rights has been recognised by all civilisations and legal systems despite the questions of universality. The rationale for the universality of these rights is that they protect the dignity of every human being and enable cooperation between people. Universal treaties impose the same international legal obligations in the field of human rights on as many states as possible. Regional treaties, on the other hand, perform this function in relation to a group of states. They may be a stage in reaching full agreement on a universal scale, not only as to the catalogue of rights, but also the methods of their implementation. The pluralism of regional systems in some way also indicates the participation of these systems in universality. Therefore, it seems that both universal and regional treaties should be applied complementarily, because only then can an individual effectively rely on this international instrument, which gives them a more complete and effective protection of their rights. Only an interpretation of the complementary application of the treaties will guarantee the fullest protection of human rights.

\section{REFERENCES}

Balcerzak, Michał. Podstawy międzynarodowej ochrony praw cztowieka. Toruń: Towarzystwo Naukowe Organizacji i Kierownictwa „Dom Organizatora”, 2017. Buergenthal, Thomas. "International and Regional Human Rights Institutions: Some Exemples of their Interaction." Texas International Law Journal 12 (1977): 321-326.

Dhommeaux, Jean. "Universalisme et régionalisme(s)." In Dictionnaire des Droits de l'Homme, dir. Joël Andriantsimbazovina, Hélène Gaudin, Jean-Pierre Marguénaud, Stéphane Rials, and Frédéric Sudre, 959. Paris: Quadrige/PUF, 2008.

Kälin, Walter, and Jörg Künzli. The Law of International Human Rights Protection. Oxford: Oxford University Press, 2010.

Lubiszewski, Maciej. "Kodyfikacja ochrony praw człowieka w systemach regionalnych." In Prawa cztowieka i ich ochrona, edited by Bożena Gronowska, Tadeusz Jasudowicz, Michał Balcerzak, Maciej Lubiszewski, and Rafał Mizerski, 78-79. Toruń: Wydawnictwo Dom Organizatora, 2010. 
Michalska, Anna. Prawa cztowieka w systemie norm międzynarodowych. Warszawa \& Poznań: Państwowe Wydawnictwo Naukowe, 1982.

Orzeszyna, Krzysztof, Michał Skwarzyński, and Robert Tabaszewski. Prawo międzynarodowe praw cztowieka. Warszawa: C.H. Beck, 2020.

Orzeszyna, Krzysztof, and Robert Tabaszewski. "The legal activities taken by local authorities to promote sustainable development goals: Do the Polish local authorities need to adopt new local strategies?." Lex Localis - Journal of Local Self-Government 4 (2021).

Osiatyński, Wiktor. Prawa cztowieka i ich granice. Kraków: Znak, 2011.

Rainer, Arnold. "Reflections on the Universality of Human Rights." Ius Gentium: Comparative Perspectives on Law and Justice, no. 1 (2013): 1-12.

Robertson, Arthur Henry. Human Rights in Europe. Manchester: Manchester University Press, 1963.

Robertson, Arthur Henry. Human Rights in the World. Manchester: Manchester University Press, 1972.

Tabaszewski, Robert. "Achieving the Sustainable Development Goals in Europe and East Asia: role of region-al organizations in monitoring right to good health and well-being." Ius Novum 2 (2019): 250-269. https://doi.org/ 10.26399/iusnovum.v13.2.2019.25/r.k.tabaszewski.

Tabaszewski, Robert. "Międzyamerykański Trybunał Praw Człowieka jako panamerykański organ sądowniczy." In Krzywicka, Katarzyna, and Joanna Kaczyńska. Oblicza Ameryki Łacińskiej. Lublin: Wydawnictwo UMCS, 2010.

Tabaszewski, Robert. "The Permissibility Of Limiting Rights And Freedoms In The European And National Legal System Due To Health Protection." Review of European and Comparative Law 3 (2020): 53-89. https://doi.org/ 10.31743/recl.6100. 